\title{
PSORIAZINE ARTROPATIJA SERGANČIŨJŲ, HOSPITALIZUOTŲ 2013 METAIS DERMATOVENEROLOGIJOS CENTRE, ANALIZĖ
}

\author{
Dalia Pacevičiūtè ${ }^{1}$, Vaitiekus Julius Lavinskas' ${ }^{1}$, Tatjana Orlovskytè ${ }^{1,2}$, Jonas Lauraitis ${ }^{2}$, \\ Matilda Bylaitė-Bučinskiene் $\dot{e}^{1,2}$ \\ IVilniaus universiteto Medicinos fakultetas, ${ }^{2}$ Vilniaus universiteto Dermatovenerologijos centras
}

Raktažodžiai: psoriazé, psoriazinė artropatija, sąnarių skausmai, PASI, gyvenimo kokybė, neịgalumas.

\begin{abstract}
Santrauka
Psoriazinè artropatija - tai lètinè, autoimuninè, progresuojanti liga, iki 30 proc. psoriaze sergančiųuc sukelianti negrịžtamus sąnarių pakitimus, lemiančius neịgalumą.

Darbo tikslas. Išanalizuoti 2013 m. VUL SK Dermatovenerologijos skyriuje hospitalizuotų psoriazine artropatija sergančiųų duomenis.

Medžiaga ir metodai. Retrospektyviai analizuotos 2013 m. Dematovenerologijos skyriuje hospitalizuotų pacientų ligos istorijų epikrizès. Vertintas psoriaze ir psoriazine artropatija sergančiujų amžius, lytis, ligos trukmè, pasireiškimo amžius ir sunkumas pagal PASI, sąnariu pažeidimai, nusiskundimai, neigalumas ir nedarbingumo lygis bei skirtas gydymas. Statistinè duomenų analizè atlikta naudojant MS Excel statistinę programą.

Rezultatai. 2013 metais Dermatovenerologijos skyriuje iš viso gydyta 651 pacientas, iš jų 291 (45 proc.) hospitalizuotas dèl psoriazès, 121 (42 proc.) pacientui diagnozuota psoriazinè artropatija; iki 25 m. - 29 pacientai (10 proc.), nuo $25 \mathrm{~m}$. iki $60 \mathrm{~m}$. 182 pacientai (63 proc.) ir vyresni nei $60 \mathrm{~m}$. - 79 pacientai (27 proc.). Vidutiné pacientų ligos trukmé - 20 metų, vidutinis susirgimo amžius - 29 m. PASI vidurkis - 22. Pacientai, sergantys psoriazine artropatija, dažniausiai skundèsi čiurnų ir kelių skausmais - 61 pacientas (52 proc.), plaštakų - 56 (50 proc.) ir pèdu - 39 (33 proc.). Sisteminis gydymas skirtas 82 (28 proc.) stacionare gydytiems pacientams, iš kurių 54 (19 proc.) gydyti metotreksatu, 26 (9 proc.) - sisteminiais kortikosteroidais, 2 (1 proc.) pacientams taikyta ilgalaikè biologinè terapija etanerceptu. Net 186 (77 proc.) sunkia psoriazès forma
\end{abstract}

sergantieji stacionare vidutiniškai gydosi 1,1 karto per metus, po to ligos remisija trunka nuo 0,5 iki 1 metų. Dèl psoriazinès artropatijos ir gretutinių ligų 25 proc. stacionare gydomų pacientų nustatytas neigalumas, o jų nedarbingumo lygis siekia 50 proc. Išvados. 2013 m. Dermatovenerologijos skyriuje dèl sunkios psoriazès gydèsi 42 proc. pacientų, iš jų net 30 proc. - dèl sunkios ligos eigos, skausmingų ir deformuotų sąnarių. Atlikus tyrimą, paaiškejjo, kad pacientai, sergantys sunkia psoriaze ir kuriems yra reikalingas stacionarinis gydymas, suserga gana anksti, vidutinis susirgimo amžius - 29 metai. Vertinant ligos sunkumą, nustatyta, kad net 69 proc. pacientų, kurie buvo hospitalizuoti ị Dermatovenerologijos skyrių, PASI reikšmè buvo didesnè nei 15 . Lietuvoje prieinamas ịvairiapusis psoriazès ir psoriazinès artropatijos ligos gydymas, kurio nepavèluotas taikymas yra būtinas, kadangi padeda išsaugoti žmogaus fizines ir socialines galimybes bei sumažina ligos simptomus.

\section{İvadas}

Psoriazè (sin. žvynelinè) - tai autoimuninè, lètinè, atsinaujinančios eigos uždegiminè odos liga, kuriai būdingas ne tik odos, nagų, bet ir sąnarių pažeidimas, taip pat psichosocialiniai bei gyvenimo kokybès pokyčiai $[1,2]$. Ivairių šaltinių duomenimis, psoriaze serga apie 2-4 proc. pasaulio gyventojų [3]. Lietuvoje tiksli psoriazès sergamumo statistika nèra žinoma, numanoma, kad serga apie 120 tūkst. gyventojų. Dažniausiai susergama iki 30 m. amžiaus, vienodai pasitaiko abiejų lyčių atstovams, susirgti gali tiek vaikai, tiek vyresnio amžiaus asmenys $[4,5]$.

Tiksli psoriazès etiologija iki šiol nèra žinoma. Ligos atsiradimą provokuoja stresas, įvairios infekcijos, traumos, genetinè predispozicija, nutukimas, rūkymas ir alkoholio vartojimas [3, 6]. Tai yra autoimuninė liga, tačiau tikslus autoantigenas iki šiol nèra nustatytas. Psoriazė vis dažniau 
yra ịvardijama kaip sisteminė uždegiminè liga, kuri gali pažeisti net kelis organus [7]. Dèl autoimuninių reakcijų ji yra susijusi su tokiomis ligomis kaip Krono liga, dislipidemija, depresija ir kardiovaskulinès ligos [3, 8]. Odos uždegimo metu išsiskiriantys mediatoriai veikia kraujagyslių endoteli, dèl to gali išsivystyti aterosklerozè, koronarinè širdies liga, širdies nepakankamumas ar miokardo infarktas $[9,10]$. Nustatyta, jog sergančių sunkia psoriaze pacientų gyvenimo trukmè sumažeja penkiais metais, palyginus su psoriaze nesergančiais to paties amžiaus asmenimis [10].

Apie 60-70 proc. pacientų serga paveldima (I tipo) psoriaze, kuri siejama su HLA genais Cw6 ir DR7 ir pasireiš-

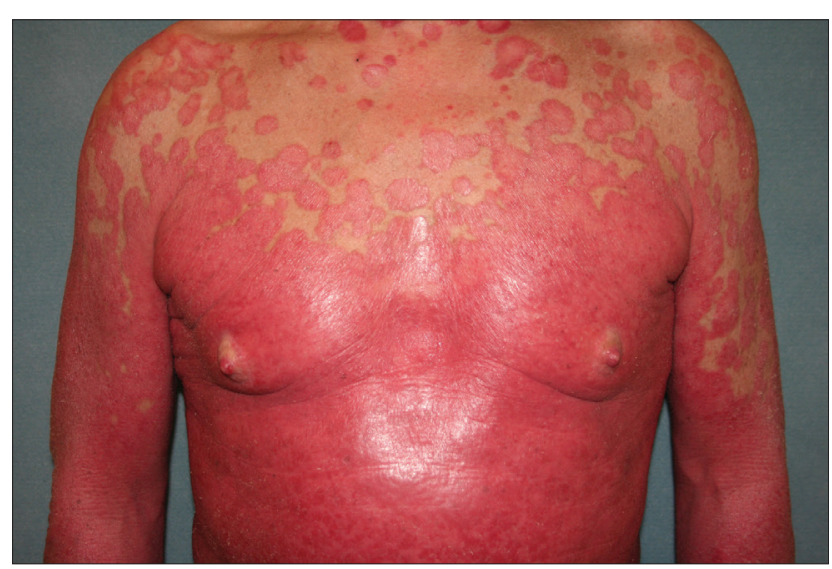

1 pav. Sunkia psoriaze sergantis pacientas: eritroderminė forma. PASI - 38 kia iki 40 metų amžiaus. Nepaveldima (II tipo) psoriazė yra lengvesnès eigos, ja suserga vyresni nei 40 metų amžiaus žmonès [2]. Ligos sunkumas vertinamas pagal PASI (psoriazès sunkumo ir pažeisto ploto indeksas, ang. Psoriasis Area and Severity Index). Šis indeksas apskaičiuojamas ịvertinus bėrimų paraudimą (eritemą), infiltraciją, pleiskanojimą ir pažeistos odos plotą. Galutine PASI reikšmè gali svyruoti nuo 0 iki 72. Esant PASI indeksui iki 10, psoriazè vertinama kaip lengvos eigos, o esant PASI per 10 - vidutinès ar sunkios eigos, kuomet rekomenduojamas sisteminis gydymas (1 pav.). Skiriamos keturios psoriazès klinikinès ligos formos: lašelinė, paprastoji plokštelinè, sunkios eigos (pustulinè, eritroderminè) ir tam tikrų sričių psoriazè. Sunkios eigos psoriazei priskiriama ir psoriazinè artropatija $[1,4,11]$.

Sergant psoriaze sąnarių pažeidimai pasireiškia iki 30 proc. atvejų [1]. Psoriazinei artropatijai atsirasti reikšmingas genetinis polinkis. Net 40 proc. sergančiujų psoriazine artopatija nurodo, kad pirmos eilès giminès serga psoriaze. Psoriazinès artropatijos atsiradimą skatina traumos, bakterinès infekcijos, nutukimas, širdies ir kraujagyslių ligos. Sergančiųjų organizme aptinkami HLA B39 ir HLA B27 antigenai. Itvykus T limfocitu ir monocitų aktyvacijai išsiskiria citokinai: TNF- $\alpha$, IL-1, IL-2 ir IL-8. Sinovijoje gausejjant neutrofilų, aktyvuotų makrofagų ir fibroblastų prasideda kremzlès destrukcija. Prasidejus augimo faktorių sintezei, skatinama naujo ektopinio kaulo proliferacija, formuojasi ataugos, kurios deformuoja sąnarius ir sukelia skausmus [7].

Psoriazinei artropatijai būdinga lètinè atsinaujinanti ar
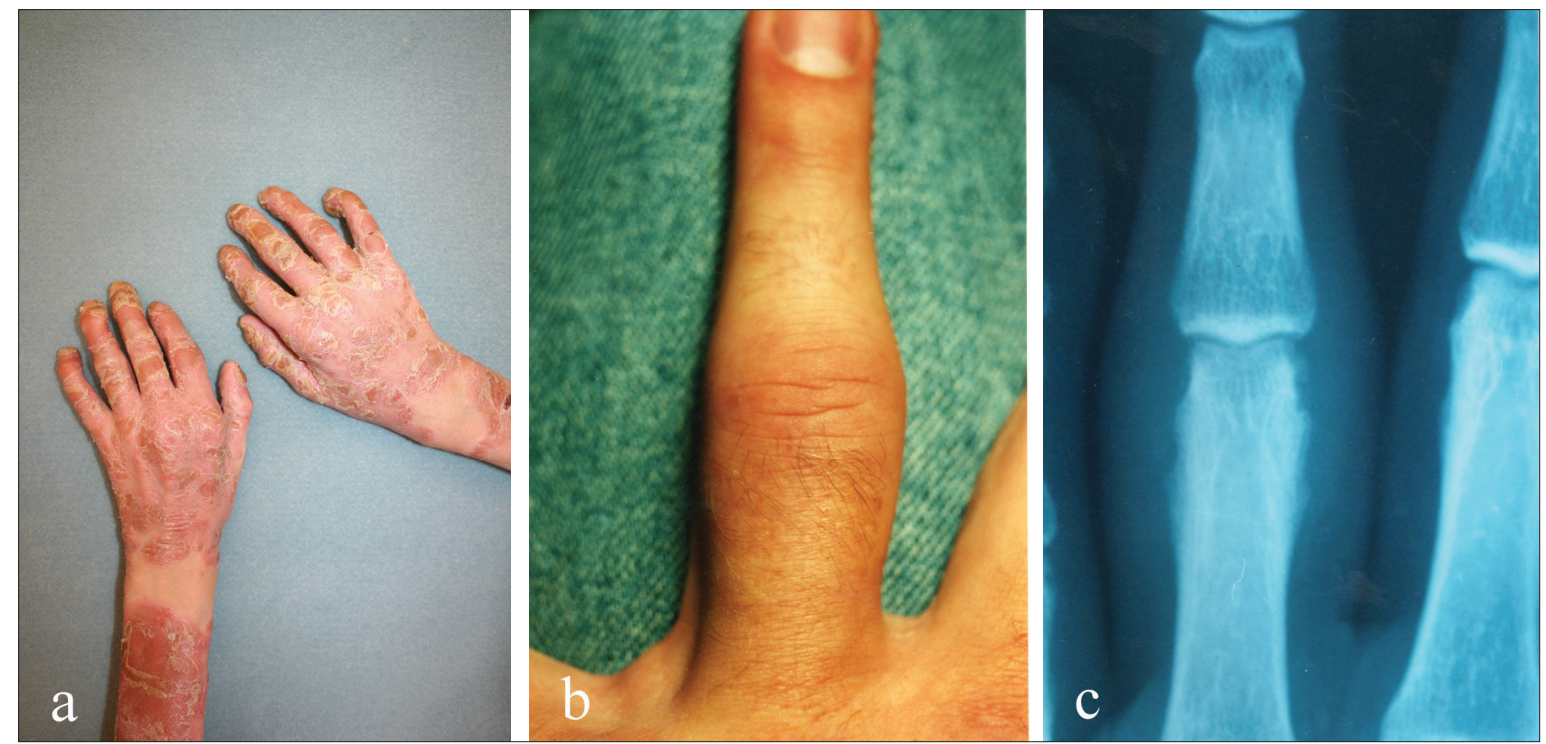

2 pav. Psoriazinès artropatijos sukelti sąnarių pažeidimai: a - deformuoti proksimaliniai ir distaliniai interfalanginiai sąnariai; b - daktilitas; c - rentgenograma: proksimalinio interfalanginio sąnario destrukcija 


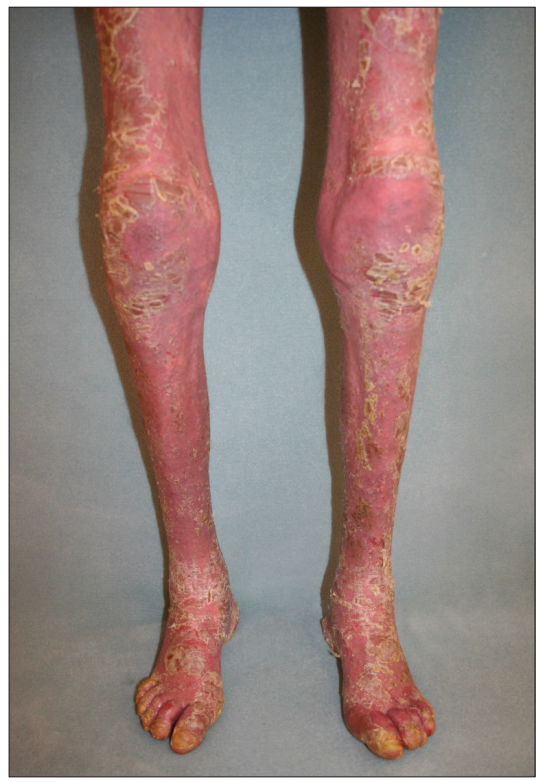

3 pav. Psoriazinès artropatijos sukelti abiejų kelių, čiurnų ir digitalinių sąnarių pažeidimai bei difuzinis odos uždegimas

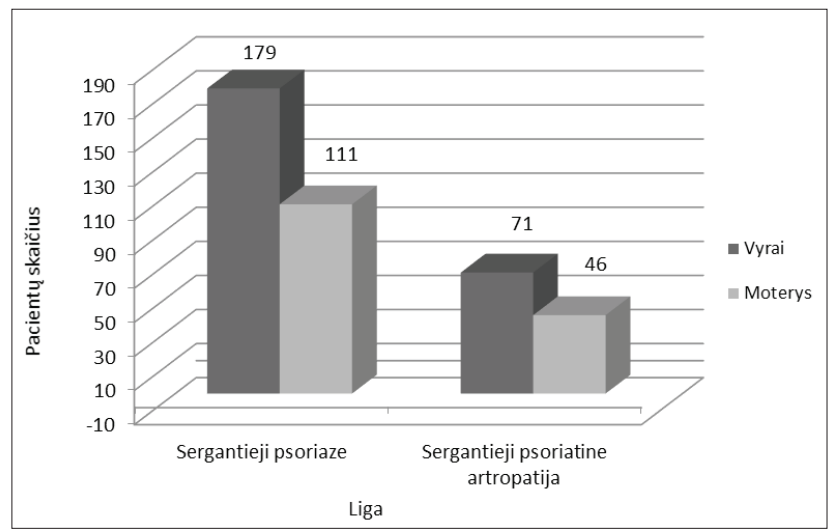

5 pav. Stacionare gydytų psoriaze ir psoriazine artropatija sergančių pacientų pasiskirstymas pagal lytị

progresuojanti eiga. Dažniausiai susergama 40-50 m. amžiuje, tačiau galimas susirgimas tiek jaunesniame, tiek ir vyresniame amžiuje. Pagal klinikinius ir rentgenologinius pakitimus skiriamos penkios psoriazinès artropatijos formos: klasikinè, mutiliacinè, poliartritinè, oligoartikulinè ir spondiloartropatinè [12]. Ligai būdingi pokyčiai apima smulkiųjų (2 pav.) ir stambiụjų sąnarių ( 3 pav.) pažeidimus, kartais su kaulinèmis ankilozèmis bei deformacijomis [12]. Kliniškai pokyčiai gali pasireikšti kaip daktilitas ar entezitas [1].

Sergant psoriazine artopatija, 26 proc. pacientu yra ne- igalūs dẻl sunkių sąnarių pažeidimų. Dirbančių ir šia liga sergančiujų darbo produktyvumas sumažèja net 46 proc., ypač esant ligos paūmejjimui ar atsiradus naujų sąnarių pažeidimams $[3,13,14]$.

Gyvenimo kokybė sergant psoriazine artropatija blogèja dèl stigmatizacijos visuomenèje (atvirose vietose matomi pleiskanojantys bèrimai, plaštakų ir nagų pažeidimai) ir itin varginančių sąnarių skausmų, sustingimo bei deformacijų (4 pav.). Netekę socializacijos galimybių dèl sumažèjusios savivertès, aplinkinių neigiamo požiūrio, nuolatinio medikamentų vartojimo, jausdami nuolatinius sąnarių skausmus ir funkcinius judesių apribojimus, pacientai šios ligos poveiki gyvenimo kokybei prilygina onkologinèms ligoms, cukriniam diabetui, kardiovaskulinèms ir kitoms sunkioms lètinèms ligoms $[1,4,15]$.

Psoriazinei artropatijai reikalingas ilgai trunkantis, sisteminis gydymas. Dažniausiai skiriamas imunosupresinis medikamentas - metotreksatas [4]. Tai citostatikas, kuris stabdo nukleino rūgščiu sintezę ir ląstelių proliferaciją. Irodyta, kad tinkamai skiriant metotreksatą, sumažeja uždegimo požymiai ir ryškiai pagerẻja gyvenimo kokybė. Taip pat metotreksatas teigiamai veikia kraujagyslių endoteli, mažinamas jo uždegimas ir kardiovaskulinių ligų vystymosi rizika [16]. Esant vidutinio sunkumo ir sunkiai plokštelinès psoriazès formai, progresuojant sąnarių pažeidimui, ypač darbingo amžiaus pacientams, kai nepadeda standartinis sisteminis ir kombinuotas su foto(chemo)terapija gydymas, reikalingas gydymas biologiniais vaistais [11]. Tai medžiagos, molekuliniame lygmenyje blokuojančios spe- 
cifinius uždegimo citokinus. Lietuvoje šiuo metu vartojami biologiniai vaistai: blokuojantys TNF- $\alpha$ - etanerceptas, infliksimabas, adalimumabas; blokuojantys interleukiną 12 (IL-12) bei interleukiną 23 (IL-23) - ustekinumabas [17]. Vartojant biologinius vaistus, ne tik daugiau nei 75 proc. pagerejja odos būklè, bet ir efektyviai slopinamas sąnarių pažeidimų progresavimas.

Mūsų darbo tikslas buvo išanalizuoti per metus Dermatovenerologijos stacionare gydytų pacientų, sergančių psoriaze, sąnarių pažeidimo dažnį, ligos sunkumą, trukmę, nusiskundimus bei nedarbingumo lygị.

\section{Tyrimo medžiaga ir metodai}

Retrospektyviai analizuotos $2013 \mathrm{~m}$. Dematovenerologijos skyriuje, kuriame yra 25 lovos, hospitalizuotu pacientų ligos istorijų epikrizès. Vertintas psoriaze ir psoriazine artropatija sergančiųų amžius, lytis, ligos trukmè, pasireiškimo amžius ir sunkumas pagal PASI, sąnarių pažeidimai, nusiskundimai, neiggalumas ir nedarbingumo lygis bei skir-

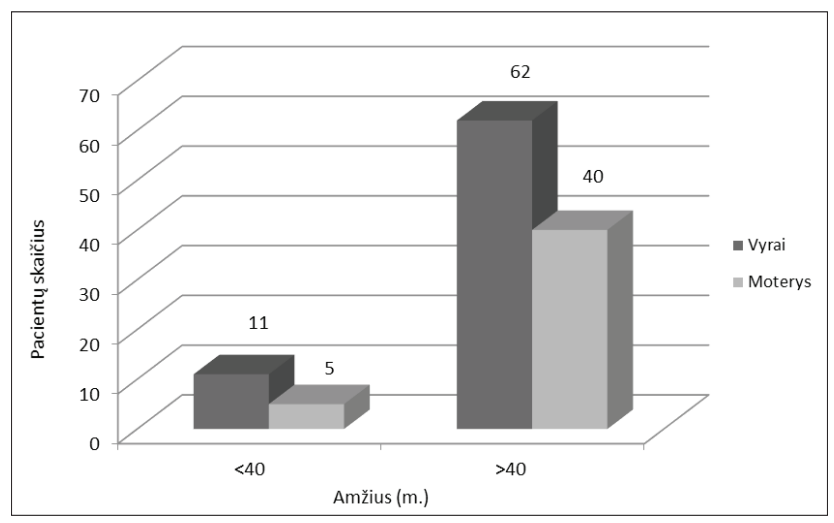

6 pav. Stacionare gydytų pacientų sergamumas psoriazine artropatija pagal lytị ir amžių.

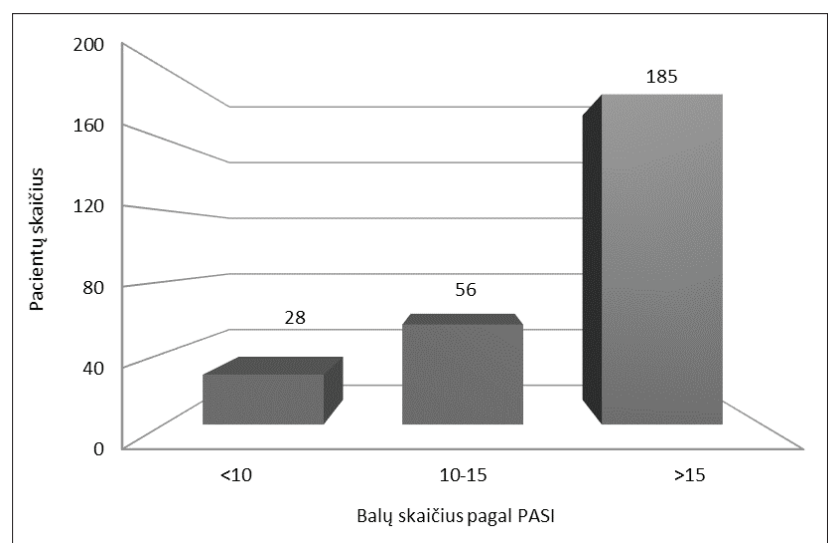

7 pav. Stacionare hospitalizuotų pacientų pasiskirstymas pagal PASI. tas gydymas. Statistinè duomenų analizė atlikta naudojant MS Excel statistinę programą.

\section{Rezultatai}

Atlikus retrospektyvinę dokumentų analizę nustatyta, kad 2013 metais Dermatovenerologijos skyriuje iš viso gydyta 651 pacientas, iš kurių 291 (45 proc.) hospitalizuoti dèl psoriazès ar psoriazinès artropatijos. Išsiaiškinta, kad 179 (62 proc.) psoriaze sergančiuju buvo vyrai, 111 (38 proc.) - moterys. Psoriazinè artropatija nustatyta $121(42$ proc.) sergančiam psoriaze, iš jų 71 (40 proc.) vyrui ir 46 (41 proc.) moterims (5 pav.).

Analizuojant hospitalizuotų sergančiųų psoriaze pasiskirstymą pagal amžių, išskirtos trys amžiaus grupès: iki 25 m. - 29 pacientai (10 proc.), nuo 25 m. iki 60 m. - 182 pacientai (63 proc.) ir vyresni nei $60 \mathrm{~m}$. - 79 pacientai (27 proc.). Nustatyta, jog hospitalizuotų pacientų psoriazės tru-

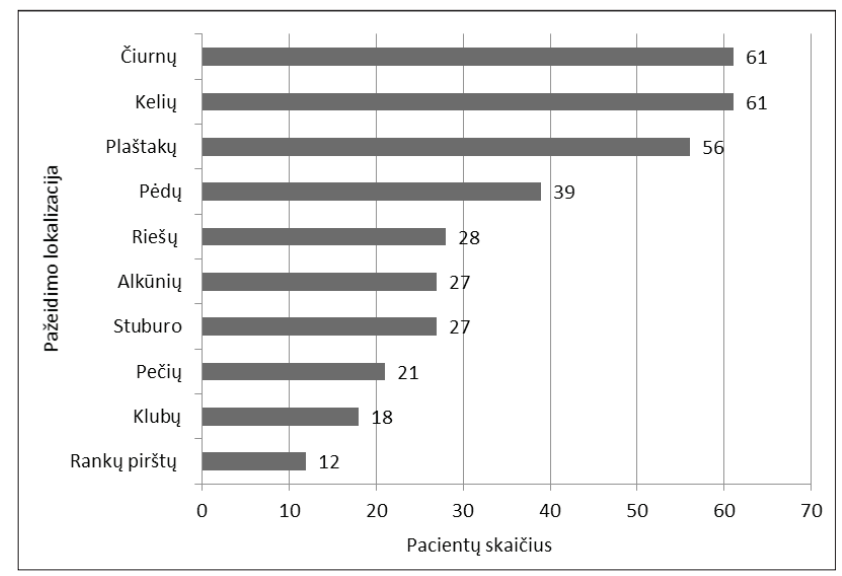

8 pav. Stacionare hospitalizuotų pacientų sąnarių pažeidimai sergant psoriazine atropatija.

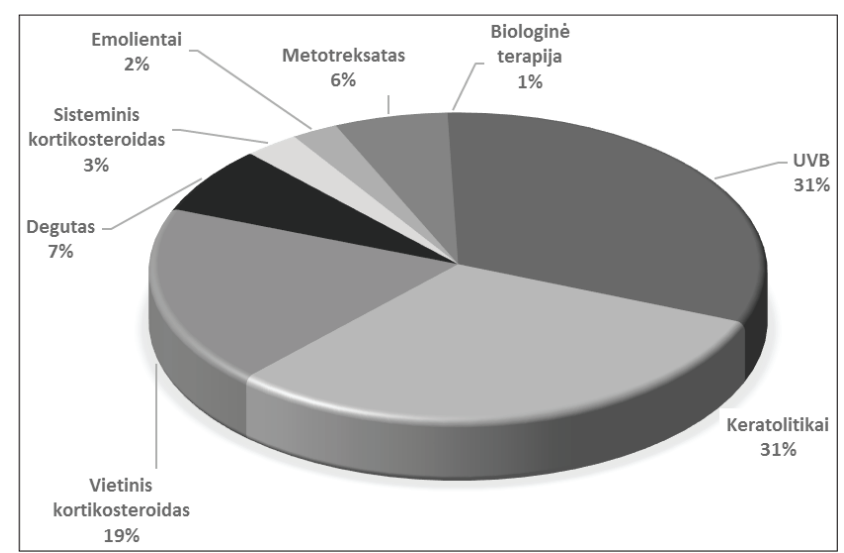

9 pav. Stacionare hospitalizuotų pacientų, sergančių psoriaze, gydymas. 
kmè svyravo nuo 1 iki 63 metų, vidutiniškai - 20 metų. Pacientu amžius diagnozuojant ligą buvo nuo 2 iki 86 metų, vidutiniškai - 29 metai.

Sergamumas psoriazine artropatija palygintas skirtingose amžiaus grupèse. Amžiaus grupejje iki $40 \mathrm{~m}$. psoriazine artropatija sirgo 16 pacientų (13 proc.), iš jų 11 (69 proc.) vyrų ir 5 (31 proc.) moterys. Vyresnių nei $40 \mathrm{~m}$. amžiaus grupejje - 102 asmenys (87 proc.), vyru - 62 (61 proc.), moterų - 40 (39 proc.) (6 pav.).

Tyrimo metu atsižvelgta ị pacientų PASI, kuris apskaičiuojamas kiekvienam hospitalizuotam ị skyrių pacientui, įvertinus eritemos, infiltracijos, pleiskanojimo stiprumą bei pažeistos odos plotą. PASI indekso reikšmé suskirstyta ị 3 intervalus: PASI iki 10 nustatyta 28 pacientams (10 proc.), nuo 10 iki 15 - 56 (21 proc.), daugiau nei 15 - 185 (69 proc.) pacientams (7 pav.). Paskaičiuotas ryšys tarp sąnarių pažeidimų ir PASI bei ligos trukmès ir PASI, tačiau koreliacijos tarp šių rodiklių nestebėta.

Nustatytos dažniausios tiriamųjų pacientų pažeistų sąnarių ( $\mathrm{n}=121)$ lokalizacijos. Čiurnų ir kelių sąnariai buvo pažeisti 61 (52 proc.) pacientui, plaštakų - 56 (50 proc.), pèdų - 39 (33 proc.), riešų - 28 (24 proc.), alkūnių ir stuburo - 27 (23 proc.), pečiu - 21 (18 proc.), klubų - 18 (15 proc.), ranku pirštu - 12 (10 proc.) pacientų (8 pav.). Sąnariu skausmų trukmès vidurkis 5,3 metai. Atskirai išanalizavus stuburo skausmų dažnị nustatyta, jog iš pirmosios amžiaus grupès ( $<40 \mathrm{~m}$.; 77 pacientų ( 27 proc.), stuburo skausmais skundèsi 2 (3 proc.) asmenys. Tačiau tarp vyresnių nei 40 metų pacientų šie skausmai buvo dažnesni ir pasireišké 25 (11 proc.) pacientams. Dažniausiai stuburo skausmas buvo lokalizuotas juosmeninejje dalyje - 22 (79 proc.) ir žymiai rečiau kitose srityse: krūtininèje - 3 (11 proc.), kryžmeninèje - 2 (7 proc.) ir kaklo srityje - 1 (4 proc.).

Dermatovenerologijos skyriuje psoriaze sergantiesiems taikytas vietinis, sisteminis ir kombinuotas gydymas. Daugumai - 277 (95 proc.) pacientams skirta siaurabangè (311 nm) UVB fototerapija, 274 (94 proc.) pacientams - keratolitiniai preparatai, 63 (22 proc.) - deguto preparatai, ir 168 (58 proc.) - vietiniai kortikosteroidai. Sisteminis gydymas skirtas 82 (28 proc.) stacionare gydytiems pacientams, iš kurių 54 (19 proc.) gydyti metotreksatu, 26 (9 proc.) - sisteminiais kortikosteroidais, 2 ( 1 proc.) pacientams taikyta ilgalaikè biologinė terapija TNF- $\alpha$ inhibitoriumi - etanerceptu (9 pav.). Fotochemoterapija (PUVA) psoriazès gydymui stacionare $2013 \mathrm{~m}$. - netaikyta.

Nustatyta, kad 186 (77 proc.) sunkia psoriazès forma sergantieji stacionare gydosi 1-2 kartus per metus, vidutiniškai 1,1 karto per metus, o vidutine gydymo stacionare trukmé - 13 dienų. Po gydymo stacionare ligos remisija dažniausiai trunka nuo 0,5 iki 1 metų. Dèl psoriazinès artropatijos ir gretutinių ligų, 25 proc. stacionare gydomų pacientų yra nustatytas neigalumas, o jų nedarbingumo lygis siekia 50 proc.

\section{Diskusija}

Psoriazė tampa vis aktualesne problema visuomenèje. Jeigu liga yra sunkios formos ir sunkiai koreguojama vaistais, pacientų gyvenimo kokybè blogèja panašiai, kaip sergant piktybiniais navikais, cukriniu diabetu ar širdies nepakankamumu. Net lengva psoriazès forma sergantys pacientai sunkiai susitaiko su liga, drovisi jos viešumoje, patiria stresą šeimoje ir darbe $[5,18]$.

Nustatyta, kad Dermatovenerologijos skyriuje 2013 m. beveik pusè (45 proc.) pacientu buvo hospitalizuoti ir gydyti dèl psoriazès. Per metus dèl psoriazès gydyta daugiau vyrų. Jie sudare $2 / 3$ pacientų, kas paaiškintų, kad vyrai dažniau serga sunkesne ligos forma, ir ne visada laikosi gydytojo nurodymų gydantis ambulatoriškai. Taip pat ligos eigą reikšmingai koreguoja jų prastesnès socialinès ar gyvenimo sąlygos bei žalingi ịpročiai.

Tyrimas parodè, kad pacientai, kuriems reikalingas stacionarinis gydymas, psoriaze suserga gana anksti, vidutinis susirgimo amžius - 29 metai. Itvertinus ligos trukmę ir susirgimo amžių nustatyta, jog daugiau pacientų serga I tipo psoriaze, kuri yra susijusi su paveldejjimu ir sunkesne ligos eiga [19]. Susirgus psoriaze ankstyvame amžiuje, ypač progresuoja dauginiai sąnarių pažeidimai dèl kurių jauni ir vidutinio amžiaus gyventojai tampa nedarbingi [17]. Svarbu, kad stacionare vidutiniškai dvi savaites gydyti daugiau nei pusè vyrų yra darbingo amžiaus ( $25-60 \mathrm{~m}$.). Tuo metu jie negali prisidèti prie visuomenès ekonominio vystymosi, o neretai jiems patiems reikalinga socialinè ir finansinè valstybès pagalba.

Vertinant ligos sunkumą nustatyta, kad net 69 proc. pacientu, kurie buvo hospitalizuoti i Dermatovenerologijos skyrių, PASI reikšmė buvo didesnè nei 15 . Toks rezultatas būdingas sunkiai kontroliuojamai psoriazès eigai. Tillett $2014 \mathrm{~m}$. atlikto tyrimo duomenimis, būtent psoriazinè artropatija lemia didesnị neigalumą lyginant su paprastaja psoriaze, net kai PASI reikšmè yra labai didelè [19].

Ištyrus visus hospitalizuotus ir psoriaze sergančius pacientus paaiškèjo, jog beveik pusei jų kartu diagnozuota psoriaziné artropatija. Naujausių tyrimų duomenimis, nustatyta, kad sergantys psoriazine artropatija pacientai netenka net 46 proc. produktyvumo darbe, lyginant su jų darbingumu iki susergant šia liga [19].

Mūsų stacionare psoriazine artropatija sergantiesiems dažniausiai pažeidžiami čiurnų, kelių bei plaštakų sąnariai. 
Stuburo skausmai sudarè 23 proc. visų sąnarių pažeidimų, kurie sergant psoriazine artropatija yra laikomi stipriai invalidizuojančiu veiksniu. Sergantiems psoriazine artropatija darbingumą ypač sumažina būtent stuburo sąnarių pažeidimai, o ne amžiniai degeneraciniai jų pakitimai [19].

Ištyrus stacionare skirtus gydymo metodus paaiškèjo, kad daugiau nei pusei psoriaze sergančių pacientų skirtas sisteminis gydymas metotreksatu, net trys ketvirtadaliai iš jų taip pat sirgo ir psoriazine artropatija. Paskutinių tyrimų duomenimis, esant sunkiai psoriazès formai ir progresuojančiam sąnarių pažeidimui, būtina laiku pradèti gydymą sisteminiais uždegimą mažinančiais vaistais ir pakankamomis jų dozėmis. Tinkamai skiriant metotreksatą regresuoja ligos klinikiniai požymiai ir pagerẻja gyvenimo kokybė [16]. Esant neefektyviam arba netoleruojamam sisteminiam gydymui, pacientams skiriama biologine terapija iš centralizuotai perkamų vaistu sąrašo. Šie medikamentai Lietuvoje skiriami Vilniaus universiteto ir Lietuvos sveikatos mokslų universiteto (LSMU) ligoninėse, po gydytojų konsiliumo pritarimo. Be medikamentinio gydymo taip pat svarbus ir gydymas balneoterapija bei kitų rūšių fizioterapija. Lietuvoje, kitaip nei kitose šalyse, sergantiesiems sunkia psoriazès forma pacientams beveik neịmanoma gauti reabilitacinio gydymo, nors patys pacientai pabrěžia, kad ligos remisija po reabilitacinių procedūrų, ypač odos bèrimų atžvilgiu, trunka iki $1 \mathrm{~m}$.

Sergant psoriaze ypač aktuali psichologinè pacienty sveikata. Vienas dažniausių šios ligos metu išsivystančių psichikos sutrikimų yra depresija, kurios dažnis dideja esant sunkiai psoriazès formai, pvz., psoriazinei artropatijai $[4,17] .2010 \mathrm{~m}$. Lietuvoje atlikto mokslinio tyrimo duomenimis, net 62 proc. psoriaze sergančių pacientų jaučia diskomfortą eidami pas kirpèją, 18 proc. pacientų labiausiai vargina ne pati liga, bet aplinkinių požiūris: net 70 proc. sergančiųjų vengia situacijų, kurių metu aplinkiniai gali pastebėti jų odos bérimus, 40 proc. pacientų girdi artimujų priekaištus, 37 proc. liga sukelia sunkumų bendraujant su partneriu, 15 proc. sergančiujų aplinkybės privertẻ keisti profesiją, o 14 proc. prieš pasirinkdami profesiją atsižvelgè i tai, kad serga psoriaze [5].

Psoriazine artropatija yra sunki psoriazès forma, kuri itin neigiamai paveikia ligonių gyvenimo kokybę ir darbingumą. Beveik pusei hospitalizuotų pacientų pasireiškia ìvairių sąnarių pažeidimai, jie greitai progresuoja ir stipriai paveikia fizines funkcijas, darbingumą bei sukelia neigalumą, ypač jei psoriazè pasireiškia ankstyvame amžiuje. Lietuvoje prieinamas ịvairiapusis šios ligos gydymas, kurị taikyti yra būtina ir laiku, nes tai padeda išsaugoti žmogaus fizines ir socialines galimybes bei sumažina ligos simptomus.

\section{Literatūra}

1. Kivelevitch D, Mansouri B, Menter A. Long term efficacy and safety of etanercept in the treatment of psoriasis and psoriazic arthritis. Biologics 2014; 8:169-182.

2. Jasaitienė D., Marčiukaitienė I.O., Valiukevičienė S., Bylaitė M. Žvynelinès sisteminio gydymo ir fototerapijos metodika. Metodinès rekomendacijos. Kaunas, 2010.

3. Parisi R, Symmons DP, Griffiths CE, Ashcroft DM. Global epidemiology of psoriasis: a systematic review of incidence and prevalence. J Invest Dermatol 2013; 2:377-85.

4. Patrihana D. Ormerod AD, Saiag P, Smith C, Spuls PI. European S3-Guidelines on the systemic treatment of psoriasis vulgaris. JEADV 2009; 2:1-70.

5. Vidraitė A., Bylaitè M. Gyvenimo kokybè sergant psoriaze. VU MF SMD LXII konferencija. Darbų tezès. Vilnius, 2010.

6. Ghoreschi K, Roecken M. Immunopathogenese der psoriasis. JDDG 2003; 7:524-531.

7. Baranauskaitė A., Eviltis E., Labanauskaitė-Šliumbienė G., Misiūnienė N., Norkuvienė E., Petraitis M., Pileckytė M., Tamulaitienė V., Sabaliauskienė J. Reumatologijos pagrindai. Kaunas, 2010.

8. Menter A, Gottlieb A, Feldman SR, Van Voorhees AS, Leonardi CL. Guidlines of care for D management of psoriasis and psoriazic arthritis: section 1. Overview of psoriasis and guidlines of care for the treatment of psoriasis with biologics. J Am Acad Dermatol 2008; 58:826-900.

9. De Vlam K, Gottlieb AB, Mease PJ. Current Concepts in Psoriazic Arthritis: Pathogenesis and Management. Acta Derm Venereol 2014; 94:627-634.

10. Ni C, Chiu MW. Psoriasis and comorbidities: links and risks. CCID. 2014; 7:119-132.

11. Marčiukaitienė I. O., Lapinskaitė G., Valiukevičienė S., Čeburkovas O., Lauraitis J., Petkevičius A. Žvynelinės diagnostika ir gydymas. Metodinė mokomoji priemonè. Vilnius, 2004.

12. JungTai Lui, HorngMing Yeh, Shyun-Yeu Liu, Kow-Tong Chen. World J Orthop 2014; 5:537-543.

13. Finaly AY, Coles EC. The effect of severe psoriasis on the quality of life 369 patient. Br J Dermatol 1995; 132:236-44.

14. Augustin M, Alvaro-Gracia JM, Bagot M, Hillmann O. A framework for improving the quality of care for people with psoriasis. JEADV 2012; 26:1-6.

15. Sampogna F, Sera F, Abeni D. Measures of clinical severity, quality of life, and psychological distress in patients with psoriasis: a clucter analysis. J Invest Dermatol 2004; 122:602-607.

16. Lie E, van der Heijde D, Uhlig T. Effectiveness and retention rates of methotrexate in psoriazic arthritis in comparison with methotrexate-treated patients with rheumatoid arthritis. Ann Rheum Dis 2010; 69:671-676.

17. Šutaitė I., Kisielienė I., Jasaitienė D., Valiukevičiūtė S., Marčiukaitenè I., Bylaitė M. Psoriazè: epidemiologija, klinika, diagnostika ir gydymas. Lietuvos gydytojo žurnalas, 2009; 8 .

18. Valiukevičienè S. Psoriazè - liga visam gyvenimui. Lietuvos 


\section{4}

gydytojo žurnalas, 2009; 8:32-42.

19. Tillett W, Shaddick G, Askari A, Cooper A, Creamer P. Work disability in psoriazic arthritis. Rheumatology 2014; 10:263-268.

ANALYSIS OF THE PATIENTS HOSPITALISED WITH PSORIAZIC ARTHRITIS IN VUH SANTARISKIU CLINICS CENTRE OF DERMATOVENEOROLOGY 2013

D. Pacevičiūtė, V. J. Lavinskas, T. Orlovskytė, J. Lauraitis, M. Bylaitė-Bučinskienè

Key words: psoriasis, psoriatic arthritis, joint pain, PASI, quality of life, disability.

Summary

Psoriatic arthropaty - chronic, autoimmunive, progressing and $30 \%$ of all cases deformating joints severe psoriasis illness, that causes disability.

The aim of the research: To analyse the patients with psoriatic arthritis who were hospitalised in Vilnius University Santariskiu Clinics Centre of Dermatoveneorology during the year of 2013.

Methodology: Retrospective analysis was performed for patients with psoriasis and psoriatic arthritis who were hospitalised in VUH SC Centre of Dermatovenerology during the year of 2013. We have evaluated patients diagnosed with psoriasis and psoriatic arthritis, their sex, age, lenght of the illness, age of diagnosing psoriasis, severity according PASI, joint infingements, complaints, treatment, disability and level of work abilities. Data analysis was made using , "Excel" statistical software.

Results: Totally 651 patients were treated in Centre of Dermatovenereology during the year of 2013. 291 (45\%) patients were hospitalised with diagnosis of psoriasis, 121 (42\%) of them were also diagnosed with psoriatic arthritis. At the age group to 25 years old $29(10 \%)$ patients were diagnosed with psoriatic arthritis.
There were $182(63 \%)$ patients at the age group between 25 and 60 years old with psoriatic arthritis. Over 60 years old there were $79(27 \%)$ patients suffering from psoriatic arthritis. Average lenght of psoriasis in hospitalised patients was 20 years, average age of patients when first time diagnosed with psoriasis was 29 years. The average meaning of PASI was 22. Patients diagnosed with psoriatic arthritis most oftenly complained of these joint pains: ankles and knees - 61 patient (52\%), palm joints - $56(50 \%)$, feet - $39(33 \%)$, wrists - $28(24 \%)$, elbows and spine - 27 (23\%), shoulders - 21 $(18 \%)$, hips - $18(15 \%)$, palm fingers - $12(10 \%)$. Systemic treatment was applied totally for $82(28 \%)$ hospitalised patients: 54 $(19 \%)$ were prescribed methotrexate, $26(9 \%)$ patients - systemic corticosteroids, 2 (1\%) patients - biological therapy with etanercept. $186(77 \%)$ patients with severe psoriasis are hospitalised in average 1,1 time per year, remision remains 0,5 to 1 year. At least $25 \%$ hospitalised with psoriasis or psoriatic arthritis have disability, their work posibilities are reduced to $50 \%$.

Conclusions: According to research during the year of 2013 there were hospitalised 121 patients with diagnosis of psoriatic arthritis. Even $30 \%$ of them had joint infringements and severe course of the illness that caused disability. Most of them psoriatic arthritis occured at the young and working age. Evaluating severity of the psoriasis we discovered that $69 \%$ patients hospitalised in 2013 had PASI higher than 15. In Lithuania there is possible to get appropriate treatment for psoriasis and psoriatic arthritis. It is aproved that applying correct treatment patients can reduce symptoms and maintain their physical abbilities.

Correspondence to: tatjana.orlovskyte@gmail.com

Gauta 2014-11-21 